\title{
Assessment and Selection of Contractors in Specific Contracting Projects with Supply Chain Approach, Using GRAY and AHP Methods as Decision Support
}

\author{
Sara Najiazarpour ${ }^{1} \&$ Homa Pouresfandyani $^{1}$ \\ ${ }^{1}$ Department of industrial engineering, Iran University of Science \& Technology, Tehran, Iran \\ Correspondence: Sara Najiazarpour, Department of industrial engineering, Iran University of Science \& \\ Technology, Tehran, Iran. Tel: 98-912-413-9755. E-mail: saraasfat@yahoo.com
}

Received: August 27, 2018

Accepted: September 28, 2018

Online Published: March 18, 2019

doi:10.5539/mas.v13n4p51

URL: https://doi.org/10.5539/mas.v13n4p51

\begin{abstract}
In our current conditions, it is not possible for all contractors to participate in specific construction project tenders due to the social, political and many other circumstances. Therefore, employers select appropriate contractors in two qualitative and quantitative stages; the second stage criteria are more important than the first stage. In this research, different stages for the evaluation and ranking of contractors in tenders of projects with specific conditions have been investigated. Researchers have tried to provide a comprehensive and complete approach to select a more appropriate contractor as an optimization method. In the first stage of the tender, the researchers used the GRAY method to rank contractors. In the second stage, they used AHP method to assess and rank the criteria of the contractors brought to this stage. Finally, the appropriate contractor selected and announced to the employer.
\end{abstract}

Keyword: tender, hierarchical ranking, gary, contractor's evaluation and selection, decision support system

\section{Introduction}

Each administration can be considered as an organization; thus, solving various administration issues requires managing, organizing, policy-making and planning in a rational and realistic way. A satisfactory combination of human resources and material resources can meet these needs and solve the aforementioned problems (Chapra and -Meindl 2001). Implementing construction projects by contractors is one of the issues that need to be coordinated and well-planned; in particular, it needs proper and rational policies. By implementing these projects annually, billions of Rials from both public and private sectors are spent on the construction and establishment of infrastructures (Azimi-A.Pouya 2013). Today, many believe that the evaluation of tenders in the public sector are only performed by focusing on the price of tenders, which is one of the problems in this regard (HATUSH.Z 1998). By paying attention only to prices, it ignores the other basic point which leads to various issues in project completion. According to statistics, more than 1,000 projects are half-finished. Approximately 147 billion dollars are invested in such projects which have been left stagnant, and about 150 billion dollars are needed to complete all half-finished projects. Since the implementation time of these projects have been multiplied compared to the initial forecast (IRNA) ("IRNA - Development Projects Unfinished, Caught in the Trap of \$ 300 Milliard" 2015), construction projects and their accomplishment by contractors are one of the top decisions in this industry; more importantly, the selection of which contractor will implement the project is very significant.

In implementing each project, from the first step to the delivery and completion of the project, there are several factors to consider. Some of these factors include contractor selection, the supplier selection, as well as consideration of the economic and political conditions, it is important to pay attention to the issues in each sector and the lack of integration in different parts of the project. This lack of integration affects the whole chain with negative impacts on all project activities and on the community; in particular, it generates a high financial burden. The structure of construction projects is generally the same. Also, given that the optimal implementation of each new construction project is a new infrastructure in a society in order to increase the economic development of that society, there should be a double attention to this line.

This article is looking for an optimal, efficient and simple way to choose a contractor to prevent from problems during the project implementation. Therefore, with better choices, a large amount of the country's capital will be saved during the execution of the project. It should also be noted that the analysis of the conditions of the 
contractors is a multi-criteria process and is largely dependent on the uncertainty in the nature of the projects and decision-makers judgment (Singh and Tiong, 2005).

Considering the importance of construction projects for the development and welfare of a nation, it is necessary to have a contractor capable of performing the contract in the best possible way, and with the least amount of material and spiritual resources contributes to this progress. It is worth noting that certain development projects including projects that have specific geographic and environmental conditions, specific locations, and the country's security conditions or projects that technically require specific expertise are evaluated in this paper.

\subsection{Tender Process and Problem Statement}

Tender for a contract is a process among the tenderers (contractors) to select the best tenderer (contractor) qualitatively and quantitatively, in order to provide the required quality with regard to the obligations of the transaction subject which is supposed to be tendered. In each project with its own specific circumstances, after identifying the winner of the tender, the company will equip the workshop at the project site, providing the materials and consumables, and all the necessary initial qualities. Once the workshop has been completed, the project starts and till its end, the supervisor will refer to the project site to review the workflow and correct implementation of the drawings, so that the steps will proceed as expected. This process will continue until the completion of the project, its definitive delivery and operation. In the special two-stage tenders, at first, a number of qualitative criteria of companies invited to the tender are evaluated, and companies that obtain a permissible rating limit will enter to the next step short list for the main bidding. In the second step, the relevant criteria are evaluated and ultimately the winning contractor is determined. (Figure1).

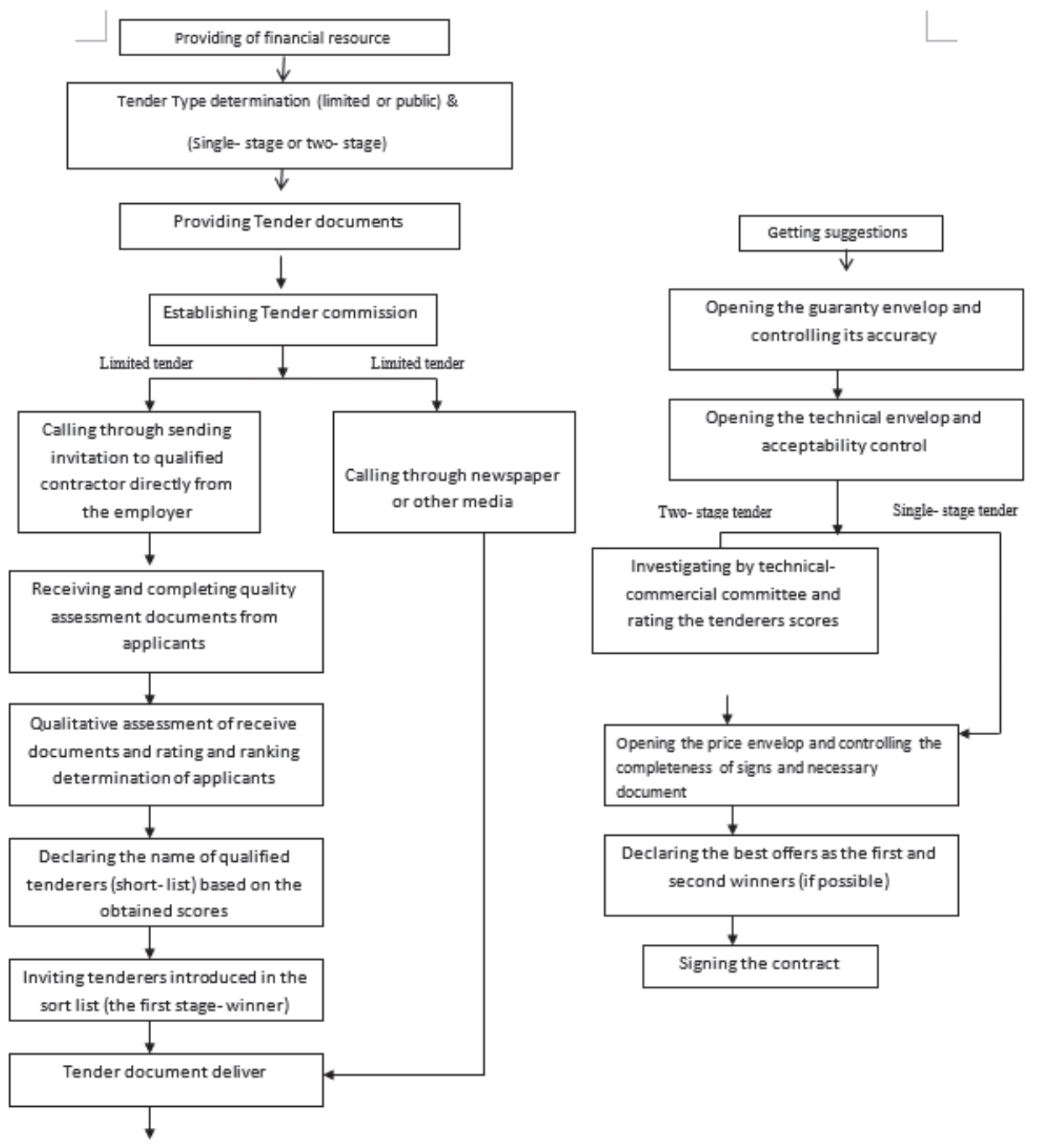

Figure 1. The procedures to choose a contractor for tenders 
Unfortunately, the contractor's improper choice based on relationships other than working conditions, neglecting the indicators, and ignoring all relevant criteria can lead to give responsibilities to the companies that are not capable (at all costs). In the end, due to different problems, they are not able to carry out the project, and after wasting time and capital, the project has not been completed, and it is among the projects that are delayed and half-finished, and many other issues will arise for the community. Failure to pay attention to the criteria at the time of choosing the contractor will make problems and challenges such as the inability of the company to pay the project costs or possible damages, the inappropriateness of the technical process of the project with outline maps, repeating part of the work, inability of people in the coordination of the project, lack of material needed for the project and so on. A high percentage of these challenges during the implementation of the project are due to reasons such as the lack of awareness of the supervisors, ignoring the conditions, factors and all the required criteria at the time of the evaluation, lack of an appropriate and integrated approach to examine the indicators at the initial stage of the construction process, that is, the selection of the contractor. It will bring inconsistencies, repetitions, and future dissipations. Such mistakes are seemingly small, but they waste massive capitals of a society, including time, budget, and superior national positions from economic, social, cultural, political point of view.

\section{Literature Review}

The lack of attention to different criteria, mental judgments and the lack of a rational and integrated technique for contractor selection caused shortcomings and problems during the implementation of the projects, which has led to extensive research in this area.

In this paper, Halt et al. (1995) reviewed the initial impacts on current methods and current trends in the UK bidding process. They also identified important weaknesses in this field and confirmed the need to revise some of the existing methods of contractor selection. They stated that in the bidding process, we should examine the contractor's ability to deliver services with an acceptable, timely and appropriately funded standard (Holt, Olomolaiye, and Harris 1995).

In another article in 1998, Halt stated that academic and industrial knowledge to judge contractor selection for construction is increasing. In recent research, the procurement decision in this regard has expanded in the United States, Britain and other countries. In this paper, the assessment of contractors, different methods and models with respect to the articles have been reviewed, which is a reflection for the future research (Holt 1998).

In a paper performed by Ebrahimi et al. (2002), a multi-criteria decision support system has been used to select the appropriate contractor. By adjusting characteristics of the project with the capabilities and work quality of contractors according to the conditions of the project, they performed an evaluation and provided a short list. Then, they compared the contractors of this list with the terms of the project using the decision support system (MCDSS) method and the AHP hierarchy analysis method(Mahdi et al. 2002).

In another article by Alarcon and Friends in 2002 aimed at introducing a contractor selection system, including predicting contractor performance, a modeling framework developed from the past research was presented. They used a conceptual model for a project that explains the structure of variables, risks, and interactions that affect the performance of the contractor in a specific project, and it helps a comprehensive assessment to identify the required information (Alarcón and Mourgues 2002).

In 2004, Cheng, Eddie, and Hong stated that choosing the right contractor in a project is one of the core activities, and this choice affects the performance of the project. Multi-criteria decision-making method (MCDM) is a continuous method for contractor selection, so Hierarchical Hierarchy Process (AHP) is the only appropriate method in decision making models and is recommended for complex issues of ANP method (Cheng and Li 2004).

Singh said in an article in 2005 that the selection of the contractor selection is only based on the price in high-risk tenders, would result in a standstill or delay in delivery and poor quality of work. Thus, in this paper, using a systematic process based on fuzzy theory, the ability of contractors to satisfy the owner's request is evaluated. Finally, it is stated that the proposed model does not replace the decision makers in the selection process of the contractor in tenders and only helps them in order to make better choices (Singh and Tiong 2005).

In 2007, Kodforces et al. stated that intra-organizational operations usually require new skills and sometimes new trends. They showed how procurement practices are influenced by goals such as innovation and collaboration. This research is based on a review of the documentation of a public tender in Sweden for partnering projects. Collaborative content has led to a focus on group work and assessment trends. This research shows that tools and logistics are focused on related contracts and are designed for local competition in two parts (Kadefors, Björlingson, and Karlsson 2007).

In 2017, Houn et al., In this paper, have focused on the importance of supply chain management in today's societies 
and industries, as well as its importance in development projects, and linked the overall chain efficiency with the choice of the best contractor initially. They used the PROMTHEE method to examine the important criteria in the tenders in order to select the best contractor (Fan et al. 2017).

Shaumann Dip et al.(2017), reviewed the selection of contractors in Indian construction, especially in the public sector, based on the lowest proposed price. At some times during these projects, they are held as a general plan, and in a table based on time delays. Based on a different contractor approach, they studied the various projects in which the winner determined on the basis of the price criterion, and finally, items such as contractor's efficiency in the work progress, suitability of the proposed price, project costs, and a number of other factors were compared (Deep, Singh, and Ahmad 2017).

In a paper by Sergere Olbilia in 2016, the ability of contractors to be chosen in foreign projects is considered as a competitive advantage, and using fuzzy model, which is a suitable model for human judgment and expressive values, quantitative and qualitative criteria have been combined and evaluated. This research was conducted on the basis of a real project and showed that the selected model was of great use and could be used as a way to reduce the risks involved in contractor selection. Also, it is an idea of how the contractor works in each decision-making criterion and the main contractor knows about their strengths and weaknesses and makes the right decision (Ulubeyli and Kazaz 2016).

Mazaheri et. Al (2013) examined the choice of the contractor using the AHP and PROMTHEE techniques. In this research, there is no reference to criteria and their perceptions (Azimi-A.Pouya 2013).

Zare Moghavadi and colleagues used MCDM, TOPSIS methods to evaluate price criteria, similar tasks, financial strength, and credibility in the selection of contractors. (Mehrjoyi-H.Momeni-Sh.Barghi 1389).

There is a huge difference in the choice of contractor in construction projects. This difference and lack of integration creates many problems in choosing. Various types of projects are carried out in Iran, in spite of the differences in their form and type (building, road and transportation, oil and gas, etc.), the way of choosing a contractor is the same for all of them with a similar overall structure. Doing projects with government or nongovernmental budgets requires economic justification in each country, so with regard to not ignoring this important issue and maintaining the conditions, in construction projects, a contractor is needed to be able to carry out the project in the best possible way, and with the smallest amount of material and spiritual resources to contribute to this progress. Therefore, the authors of this paper have tried to do this, so by designing a model and applying it in a true bid, they try to demonstrate the possibility of using the relevant outputs.

\section{Research Methods and Criteria}

In this research, after studying past research and collecting data, the criteria for the research were determined by the opinion of relevant experts and field investigations. The criteria for the first and second stages, along with the sub- criteria, are presented in Table 1.

Table 1. Main criteria and sub criteria for contractor selection

\begin{tabular}{|c|c|}
\hline main Criteria & Sub criteria \\
\hline \multirow{6}{*}{$\begin{array}{c}\text { Financial Ability } \\
\text { (confirmation is } \\
\text { only one of the } \\
\text { conditions) }\end{array}$} & first stage \\
\hline & Fixed assets \\
\hline & The last 5 years turnover \\
\hline & Gross annual income for the last 5 years \\
\hline & Credit / Bank Verification \\
\hline & Annual average tax or social security payment (definitive or explicit( \\
\hline \multirow{4}{*}{$\begin{array}{l}\text { creativity and } \\
\text { innovation }\end{array}$} & Value Engineering Certificate or Value Engineering Program \\
\hline & Research \& Development Unit (R \& D( \\
\hline & Innovations approved by the operating system \\
\hline & $\begin{array}{l}\text { Presenting internal and external articles and research and technical } \\
\text { achievements }\end{array}$ \\
\hline \multirow{2}{*}{$\begin{array}{l}\text { Equipment } \\
\text { capability }\end{array}$} & $\begin{array}{l}\text { Types of machinery related to the construction and implementation of the } \\
\text { project }\end{array}$ \\
\hline & Official buildings, office and workshop equipment \\
\hline Effici & $\begin{array}{l}\text { Manufacturing factories owned by the company } \\
\text { ranking }\end{array}$ \\
\hline management & Establishment of Quality and Safety Management System and \\
\hline
\end{tabular}




\begin{tabular}{|c|c|}
\hline Operational record & $\begin{array}{l}\text { Organizational Structure (QA, QC, HSE, HSE PLAN, ISO( } \\
\text { Training courses passed by the CEO, the board of directors and key } \\
\text { personnel of the organization } \\
\text { Membership in scientific and professional associations } \\
\text { Participation in international tenders } \\
\text { The number of accomplished works similar to the project (financially, } \\
\text { field of work and complexity of the project) in recent years } \\
\text { The number of accomplished works dissimilar to the project (financially, } \\
\text { field of work and complexity of the project) in recent years } \\
\text { The number of design work performed in similar projects (financially, } \\
\text { field of work, and complexity related to the project) in recent years (this } \\
\text { is also considered in contracts that include design( } \\
\text { The number of equipped works in similar projects (financially, field of } \\
\text { work, and complexity related to the project) in recent years (this sub- } \\
\text { criterion is included in contracts involving the supply of equipment). } \\
\text { Being native (Includes } 4 \text { modes: Native company with local Work, Non- } \\
\text { native company with local work, Native company with nonnative } \\
\text { company with Non-Local Work) }\end{array}$ \\
\hline & \\
\hline Proposed price & $\begin{array}{l}\text { Providing affordable prices, taking into account all stages of work, } \\
\text { project facilities and economic conditions } \\
\text { Consent letters } \\
\text { Commendation letters }\end{array}$ \\
\hline Good performance & $\begin{array}{l}\text { Certificate of completion at the given time limit with price stated in the } \\
\text { contract } \\
\text { Certification of the project defect elimination at the given time } \\
\text { hiring expert and skillful people (including CEO, board members and key } \\
\text { personnel( }\end{array}$ \\
\hline $\begin{array}{l}\text { Technical feasibility } \\
\text { of project planning }\end{array}$ & $\begin{array}{l}\text { The amount of relevant background in the project } \\
\text { The structure of quality assurance and project management (including } \\
\text { units: project control and related software systems - Material and } \\
\text { Manufacturing Control (QC) - Technical Office - Estimating Financial } \\
\text { Support( } \\
\text { Proposed Schedule } \\
\text { Organization structure and description of duties and responsibilities } \\
\text { Timely delivery of previous projects or completion with permitted delay }\end{array}$ \\
\hline
\end{tabular}

In the present study, GRAY and AHP methods have been used. The GRAY method is used because in this method, the range of numbers is clear, but the amount of the item itself is not clear. Due to the large amount of information and the integration of all of them, AHP has been used to obtain an optimal response. The information about the 7 applicant companies in a tender held by the Ministry of Roads and Urban Development was reviewed. In the first stage, the quality assessment of the contractors was performed using the GRAY method, then, a brief list of contractors who had obtained the required score was prepared. In calculations, $0.5=\xi$ and the importancecoefficient of the criteria ((REFRENCE POINT) has been calculated according to the experts' opinion.

$$
\begin{gathered}
r\left(x *(j), x_{\mathrm{i}}(j)\right)=\frac{\min \min \left|x *(j)-x_{\mathrm{i}}(j)\right|+\xi \max \max \left|x *(j)-x_{\mathrm{i}}(j)\right|}{\left|x *(j)-x_{\mathrm{i}}(j)\right|+\xi \max \max \left|x *(j)-x_{\mathrm{i}}(j)\right|} \\
r\left(x *, x_{\mathrm{i}}\right)=\sum_{r} w_{\mathrm{r}} \Upsilon\left(x *(j), x_{\mathrm{i}}(j)\right)
\end{gathered}
$$

Table 2. First stage of calculation with GRAY method

\begin{tabular}{cccccc} 
Gray & $\begin{array}{c}\text { Operational } \\
\text { record }\end{array}$ & $\begin{array}{c}\text { Efficient } \\
\text { management }\end{array}$ & $\begin{array}{c}\text { Financial } \\
\text { capability }\end{array}$ & $\begin{array}{c}\text { Equipment } \\
\text { capability }\end{array}$ & $\begin{array}{c}\text { creativity and } \\
\text { innovation }\end{array}$ \\
\hline
\end{tabular}




\begin{tabular}{cccccc}
\hline & system & & & \\
\hline Refrenc Point & 30 & 15 & 20 & 15 & 5 \\
\hline Company 1 & 25.75 & 11 & 10 & 13.5 & 1.5 \\
Company 2 & 22.5 & 15 & 20 & 13.5 & 2 \\
Company 3 & 18.5 & 12.5 & 16 & 7.8 & 0.5 \\
Company 4 & 16.58 & 12 & 20 & 10.5 & 0.5 \\
Company 5 & 11.12 & 12.5 & 19 & 9.9 & 0.75 \\
Company 6 & 9.9 & 10 & 11.4 & 10.4 & 1.5 \\
Company 7 & 7.25 & 13 & 6.6 & 3.3 & 1.25 \\
\hline
\end{tabular}

\begin{tabular}{cc}
\hline Min Min & 0 \\
\hline Max Max & 0.9 \\
E & 0.5 \\
\hline
\end{tabular}

Table 3. The final stage of calculation with the GRAY method and the ranking of the quality evaluation stage

\begin{tabular}{ccccccccc}
\hline $\begin{array}{c}\text { Final } \\
\text { Gray }\end{array}$ & $\begin{array}{c}\text { Operational } \\
\text { record }\end{array}$ & $\begin{array}{c}\text { Efficient } \\
\text { management } \\
\text { system }\end{array}$ & $\begin{array}{c}\text { Financial } \\
\text { capability }\end{array}$ & $\begin{array}{c}\text { Equipment } \\
\text { capability }\end{array}$ & $\begin{array}{c}\text { creativity } \\
\text { and } \\
\text { innovation }\end{array}$ & sum & $\mathbf{0 . 2 0}$ & ranking \\
\cline { 1 - 6 } $\mathrm{W}$ & 0.31 & 0.34 & 0.44 & 0.55 & 0.38 & & & \\
1 & 0.236 & 0.213 & 0.208 & 0.450 & 0.149 & 1.256 & 0.251 & 3 \\
2 & 0.199 & 0.340 & 0.440 & 0.450 & 0.163 & 1.592 & 0.318 & 1 \\
3 & 0.167 & 0.248 & 0.305 & 0.266 & 0.127 & 1.113 & 0.223 & 5 \\
4 & 0.155 & 0.235 & 0.440 & 0.330 & 0.127 & 1.288 & 0.258 & 2 \\
5 & 0.129 & 0.248 & 0.396 & 0.313 & 0.132 & 1.218 & 0.244 & 4 \\
6 & 0.125 & 0.195 & 0.225 & 0.327 & 0.149 & 1.021 & 0.204 & 6 \\
7 & 0.115 & 0.262 & 0.177 & 0.201 & 0.143 & 0.898 & 0.180 & 7 \\
\hline
\end{tabular}

In the GRAY method, the DEMATEL method was used to calculate the weight of the criteria (that is, to harmonize the opinions of experts in holding different tenders and to identify the weight of each criterion in relation to other criteria according to their importance).

$$
\begin{array}{r}
\mathrm{F}=\mathrm{D}(\mathrm{I}-\mathrm{D})^{-1} \\
f_{\text {ir }}=\left\{\begin{array}{cc}
f_{\text {ir }} & f_{\text {ir }} \geq \theta \\
0 & f_{\text {ir }} \leq \theta
\end{array}\right.
\end{array}
$$

Table 4. The first step of calculating weights using the DEMATEL method

\begin{tabular}{ccccccc}
\hline Dematel & $\begin{array}{c}\text { Operational } \\
\text { record }\end{array}$ & $\begin{array}{c}\text { Efficient } \\
\text { management } \\
\text { system }\end{array}$ & $\begin{array}{c}\text { Financial } \\
\text { capability }\end{array}$ & $\begin{array}{c}\text { Equipment } \\
\text { capability }\end{array}$ & $\begin{array}{c}\text { creativity and } \\
\text { innovation }\end{array}$ & sum \\
\hline Employer 1 & 35 & 8 & 13 & 25 & 5 & 85 \\
Employer 2 & 42 & 10 & 15 & 14 & 5 & 86 \\
Employer 3 & 60 & 10 & 10 & 10 & 6 & 96 \\
Employer 4 & 30 & 10 & 20 & 30 & 10 & 100 \\
Employer 5 & 40 & 23 & 20 & 20 & 8 & 111 \\
sum & 207 & 61 & 78 & 99 & 34 & \\
\hline
\end{tabular}

\begin{tabular}{|c|c|}
\hline Max & 207 \\
\hline o & 0.20699476 \\
\hline
\end{tabular}


Table 5. Final stage and weights calculated using the DEMATEL method

\begin{tabular}{ccccccc}
\hline Final Dematel & $\begin{array}{c}\text { Operational } \\
\text { record }\end{array}$ & $\begin{array}{c}\text { Efficient } \\
\text { management } \\
\text { system }\end{array}$ & $\begin{array}{c}\text { Financial } \\
\text { capability }\end{array}$ & $\begin{array}{c}\text { Equipment } \\
\text { capability }\end{array}$ & $\begin{array}{c}\text { creativity } \\
\text { and } \\
\text { innovation }\end{array}$ & w \\
\hline $\begin{array}{c}\text { Operational } \\
\text { record } \\
\text { Efficient }\end{array}$ & 0.31 & 0 & 0 & 0 & 0 & 0.31 \\
$\begin{array}{c}\text { management } \\
\text { system }\end{array}$ & 0.34 & 0 & 0 & 0 & 0 & 0.34 \\
$\begin{array}{c}\text { Financial } \\
\text { capability }\end{array}$ & 0.44 & 0 & 0 & 0 & 0 & 0.44 \\
$\begin{array}{c}\text { Equipment } \\
\text { capability } \\
\text { creativity and } \\
\text { innovation }\end{array}$ & 0.31 & 0 & 0 & 0.23 & 0 & 0.55 \\
\hline
\end{tabular}

Using the $\mathrm{ABC}$ analysis, among the 7 companies in the first phase, four companies that obtained $50 \%$ score or above in this process entered into the second stage of the tender. In the second phase, the technical evaluation stage, the AHP method has been used to measure incoming companies from the first stage and to choose the winner of the bidding contract. The information required for this stage was also extracted according to the tender information.

Given that the price is considered as a negative criterion in the calculation, the inverse of the proposed price in the table is used for the calculation, as well as the geometric mean method is used for calculating paired weights comparison matrix. The Gaussian function has also used to reduce wrong effects, so that with help of the mean and standard deviation, the possible effects of the mistake will be reduced.

$$
\begin{aligned}
A & =\left[\begin{array}{ccc}
\left(\mathrm{w}_{1}\right. & & \left.\mathrm{w}_{\mathrm{u}}\right) \\
a_{11} & \cdots & a_{1 \mathrm{u}} \\
\vdots & \ddots & \vdots \\
a_{\mathrm{v} 1} & \cdots & a_{\mathrm{vu}}
\end{array}\right] \\
W & =\sum_{i, r}\left(w_{\mathrm{i}} * A_{\mathrm{r}}\right)
\end{aligned}
$$




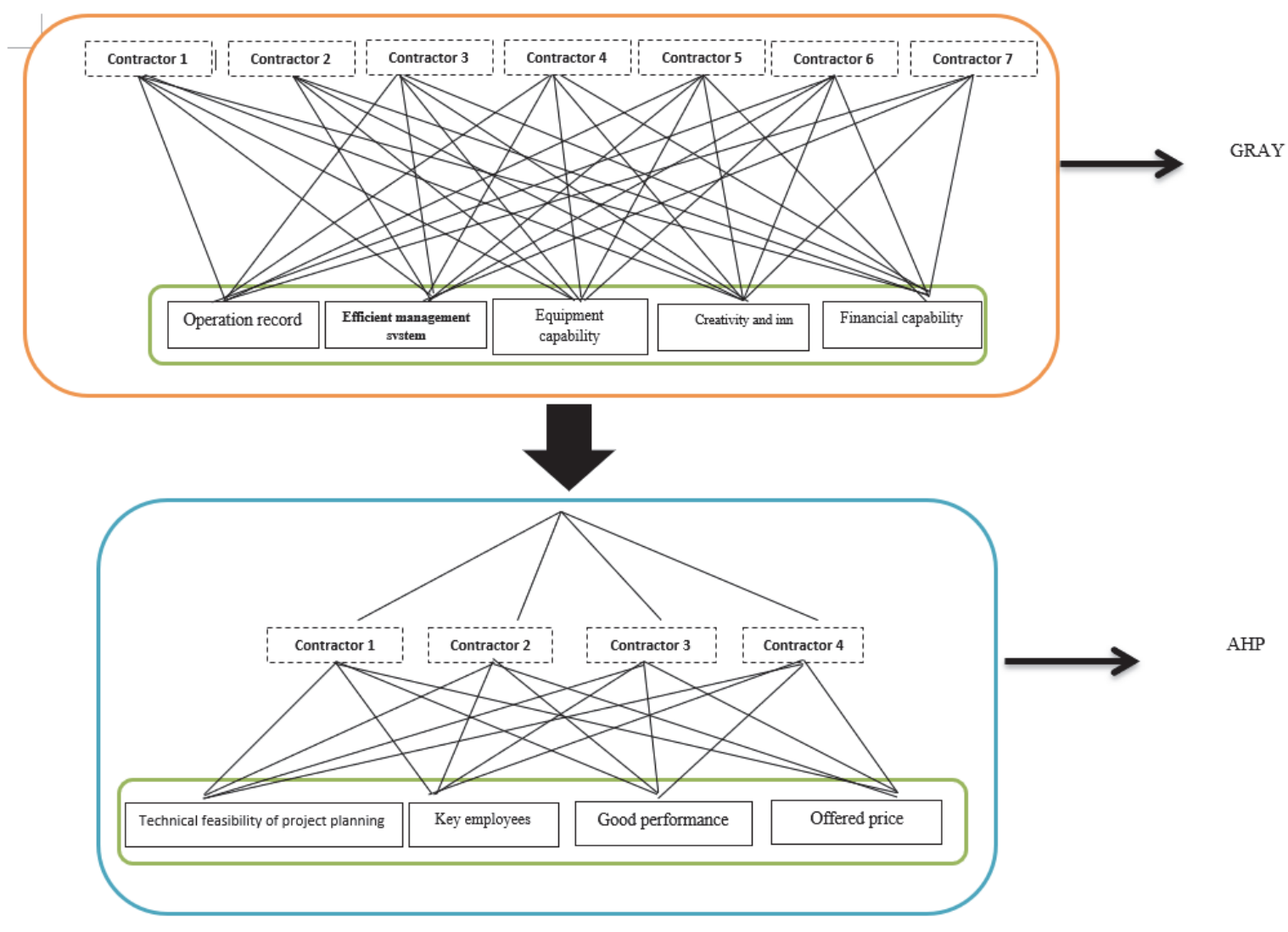

Table 6. Paired comparison matrix of AHP method steps

\begin{tabular}{ccccc}
\hline AHP & $\begin{array}{c}\text { Price } \\
\text { (million Toman) }\end{array}$ & $\begin{array}{c}\text { good } \\
\text { performance }\end{array}$ & $\begin{array}{c}\text { key employees } \\
\text { quality }\end{array}$ & $\begin{array}{c}\text { Technical feasibility } \\
\text { of project planning }\end{array}$ \\
\hline $\begin{array}{c}\text { Company } \\
\mathbf{1}\end{array}$ & $139 ، 195 ، 094 ، 094$ & 3.75 & 4 & 2.5 \\
$\begin{array}{c}\text { Company } \\
\mathbf{2}\end{array}$ & $134 ، 318 ، 348 ، 382$ & 3.5 & 5 & 2.5 \\
$\begin{array}{c}\text { Company } \\
\mathbf{4}\end{array}$ & $123 ، 883 ، 633 ، 665$ & 3 & 4 & 4 \\
Company & $167 ، 379 ، 881 ، 309$ & 5 & 3.37 & 3.75 \\
$\mathbf{5}$ & & & & \\
\hline
\end{tabular}

\begin{tabular}{ccccc}
\hline $\begin{array}{c}\text { key employees } \\
\text { quality }\end{array}$ & Company 1 & Company 2 & Company 4 & Company 5 \\
\hline Company 1 & 1 & 0.8 & 1 & 1.19 \\
Company 2 & 1.25 & 1 & 1.25 & 1.48 \\
Company 4 & 1 & 0.8 & 1 & 1.19 \\
Company 5 & 0.84 & 0.67 & 0.84 & 1 \\
SUM & 4.09 & 3.27 & 4.09 & 4.86 \\
\hline
\end{tabular}


Table 7. AHP Final Ranking

\begin{tabular}{ccccccc}
\hline Final AHP & Price & $\begin{array}{c}\text { good } \\
\text { performance }\end{array}$ & $\begin{array}{c}\text { key employees } \\
\text { quality }\end{array}$ & $\begin{array}{c}\text { Technical feasibility } \\
\text { of project planning }\end{array}$ & $\begin{array}{c}\text { final } \\
\text { weight }\end{array}$ & ranking \\
\hline $\begin{array}{c}\text { Criterion } \\
\text { weight }\end{array}$ & 0.490 & 0.169 & 0.171 & 0.168 & & \\
Company 1 & 0.99 & 0.25 & 0.24 & 0.20 & 0.60 & 1 \\
Company 2 & 0.91 & 0.23 & 0.31 & 0.20 & 0.57 & 2 \\
Company 4 & 0.56 & 0.20 & 0.24 & 0.31 & 0.40 & 3 \\
Company 5 & 0.27 & 0.33 & 0.21 & 0.29 & 0.27 & 4 \\
\hline
\end{tabular}

\section{Conclusion}

All entering contractors in a construction project evaluate by different criteria and characters. Many of those are constant for all tenders however, a few numbers may determine based on project. For optimal performance in each project and optimization the chain, MCDM methods are involved in efficient and impressive methods that in there, AHP and GRAY methods are used.

From the companies entering the final stage, Company 1 was the best choice and the winner of this tender, and the following priorities were determined accordingly. In this study, many factors have been effective in choosing a winner:

First, different and varied criteria make it easier and more precise to check the condition of a company. Second, the importance and position of each criterion were examined at each stage separately, which indicates the difference in the importance of each criterion. Finally, it is very important to use methods such as (GRAY and AHP) that can measure all the criteria at each step together and affect the weights of each criterion.

Today, the lack of using decision making methods as a single method and with a minimum error coefficient has created many problems in this choice. It should be noted that the right choice of the contractor is the most important factor in the tenders, and it is the first stage of a very large chain, so it is of great importance because it can prevent the loss of the material and spiritual resources of a society, and, at the same time, increases the overall profit of the chain. It also reduces the difficulties in the implementation of the project. Also, the use of a well-defined method ignores the long-term relationships existing among some employers in conducting tenders, and eliminates its impact.

Considering the specific conditions of the projects and the fact that the presence of each contractor in projects with special circumstances is not possible, in this research, the studies are carried out in two stages, namely qualitative and quantitative evaluations, and a short list of contractors from the first stage would enter to the second stage of the bidding process, after evaluations implemented by the GRAY method. In the second stage, the relevant criteria, which are of higher importance than the first stage criteria, were examined using the AHP method and the winning contractor was determined (Company 1).

\section{References}

Alarcón, L. F., \& Claudio, M. (2002). Performance Modeling for Contractor Selection. Journal of Management in Engineering, 18(2), 52-60. https://doi.org/10.1061/(ASCE)0742-597X(2002)18:2(52)

Azimi, A., Pouya, Y., \& Mazaherizade, Z. N. (2013). Identify and Evaluate the Effective Indicators in Choose a Contractor to Finance Water and Wastewater Company Mashhad. Sixth International Conference of Iranian Operations Research Society.

Chapra, S., \& Peter, M. (2001). Supply Chain Management. Pearson Education.

Cheng, Eddie, W. L., \& Heng L. (2004). Contractor Selection Using the Analytic Network Process. Construction Management and Economics, 22, 1021-32. https://doi.org/10.1080/0144619042000202852

Deep, S., Deepak, S., \& Syed, A. A. (2017). A Review of Contract Awards to Lowest Bidder in Indian Construction Projects via Case Based Approach. Scientific Research Publishing, 3292, 159-68. https://doi.org/10.4236/ojbm.2017.51015

Fan, H., Gang, Li, Hongyi, S., \& Cheng, T. C. E. (2017). An Information Processing Perspective on Supply Chain Risk Management: Antecedents, Mechanism, and Consequences. International Journal of Production 
Economics, 185, 63-75. https://doi.org/10.1016/j.ijpe.2016.11.015

Hatush, Z., \& Skitmore, M. (1998). Contractor Selection Using Multicriteria Utility Theory. An Additive Model, $33,105-15$.

Holt, G. D. (1998). Which Contractor Selection Methodology? International Journal of Project Management, 16(3), 153-64. https://doi.org/10.1016/S0263-7863(97)00035-5

Holt, G. D., Paul, O. O., \& Frank, C. H. (1995). A Review of Contractor Selection Practice in the U.K. Construction Industry. Building and Environment, 30(4), 553-61. https://doi.org/10.1016/0360-1323(95)00008-T

"IRNA - Development Projects Unfinished, Caught in the Trap of \$ 300 Milliard." 2015. Retrieved June 29, from Accessed http://www.irna.ir/fa/News/81468764/

Kadefors, A., Emma, B., \& Andreas, K. (2007). Procuring Service Innovations: Contractor Selection for Partnering Projects. International Journal of Project Management, 25(4), 375-85. https://doi.org/10.1016/j.ijproman.2007.01.003

Mahdi, I. M., Mike, J. R., Sami, M. F., \& Alex, P. A. (2002). A Multi-Criteria Approach to Contractor Selection. Engineering Construction and Architectural Management, 9(1). Blackwell Science Ltd.: 29-37. https://doi.org/10.1046/j.1365-232X.2002.00228.x

Mehrjoyi, H., Momeni, Sh., \& Barghi, Y. Z. (1389). Evaluation and Selection of Contractors in Petrochemical Projects, Approach Decision Making Techniques - Techniques Borda." Excavations Business Administration Journal, 32-59.

Singh, D., \& Robert, L. K. T. (2005). A Fuzzy Decision Framework for Contractor Selection. Journal of Construction Engineering and Management, 131(1), 62-70. https://doi.org/10.1061/(ASCE)07339364(2005)131:1(62).

Ulubeyli, S., \& Aynur, K. (2016). Fuzzy Multi-Criteria Decision Making Model for Subcontractor Selection in International Construction Projects. Technological and Development of Economy 4913 (March). https://doi.org/10.3846/20294913.2014.984363

\section{Copyrights}

Copyright for this article is retained by the author(s), with first publication rights granted to the journal.

This is an open-access article distributed under the terms and conditions of the Creative Commons Attribution license (http://creativecommons.org/licenses/by/4.0/). 